\title{
Organização e disciplina do trabalho ferroviário baiano no pós- abolição*
}

Robério Santos Souza*

Resumo: Este trabalho pretende compreender a maneira como foi concebida a organização do trabalho ferroviário na Bahia nos primeiros anos que se seguiram à abolição da escravidão, em 1888. A elaboração de um extenso código disciplinar em 1893 demonstra a orientação para uma "nova ética do trabalho" que pretendia disciplinar e instaurar novos valores e comportamentos nos trabalhadores. Nessa perspectiva, este artigo analisa a dimensão política da organização e do processo de trabalho ferroviário, enfatizando sobretudo os instrumentos que intentavam regular, ordenar e controlar os operários no âmbito da Estrada de Ferro do São Francisco, na Bahia.

Palavras-chave: organização do trabalho, código disciplinar, ferrovia, Bahia

Abstract: This paper aims to comprehend the way how the organization of rail work in Bahia was designed during the firsts years after emancipation of slavery, in 1888. The creation of a extensive disciplinary code in 1893 shows the orientation of a "new ethic of work" which intended to organize and impose new values and behaviors for its workers. Thus, this article wants analize the political contents of the proposal of work organization and the process of rail work itself, paying special attention to the elements which this code used to regulate it. Also we want to understand how it controled the workers which were engaged on the São Francisco Railroad in Bahia.

Keywords: organization of rail work, disciplinary code, railway, Bahia

\section{INTRODUÇÃO}

Criados pela ótica patronal, os regulamentos se multiplicaram no Brasil de fins do final do século XIX e se configuraram como um conjunto de regras e normas cada vez mais extenso, que incluíam desde prescrições morais para os operários, até dados sobre salários, multas e penalidades, suspensões e dispersão das tensões. Esses dispositivos disciplinares expressavam, em grande medida, a vontade e a expectativa dos patrões em relação ao funcionamento do trabalho e ao comportamento de seus empregados. Conforme ressaltou Michelle Perrot, "o regulamento sugere uma imagem reflexa do trabalhador e sua turbulência, ao mesmo tempo que revela sua dupla finalidade: econômica, decerto, mas

\footnotetext{
* Este artigo é resultado de uma pesquisa financiada com apoio do CNPq.

** Doutorando em História Social da Cultura pelo IFCH/UNICAMP.
} 
também profundamente política - disciplinar o corpo do trabalhador, seus gestos e seu comportamento" ${ }^{1}$.

Sob essa ótica, tanto pela via dos regulamentos que gradativamente proliferavam nas fábricas e nas indústrias, quanto pelo "sistema de fábrica com vila operária" que vislumbrava a fixação e o monitoramento da força de trabalho fora do espaço de produção, na vida doméstica, em seus momentos de lazer e sociabilidade, os setores empresariais brasileiros pretenderam manter sob o seu total domínio os trabalhadores ${ }^{2}$.

Sidney Chalhoub destaca que, entre o final do século XIX e o início do século XX, as elites brasileiras trataram de elaborar um discurso oficial que buscava positivar o trabalho, incutindo nos trabalhadores novos valores que evocavam a ordem, a laboriosidade, o progresso e a disciplina nos espaços de trabalho. Com isso, acreditavam transformar os libertos em trabalhadores, preparando-os, assim, para se integrar à nova ordem burguêscapitalista. Além disso, expressando essa mesma ideologia que intentava apagar a ideia negativa sobre o trabalho, herdada da escravidão, o aparato policial retirava das cidades os chamados "desocupados", reprimindo os considerados "ociosos" e "vadios" ${ }^{3}$. Esse autor caracterizou esse processo como uma nova ideologia do trabalho.

Condizente com essa ideologia que procurava instaurar novos valores nos trabalhadores, o trabalho ferroviário baiano, nos anos que se seguiram à abolição da escravidão, foi marcado por políticas de disciplinarização e tentativas específicas de reorganização e regulamentação do processo de trabalho. Nas ferrovias essas práticas foram traduzidas em relações de trabalho rigidamente hierarquizadas e imposições disciplinares. Entretanto, esta realidade nas ferrovias eram mecanismos que, ao mesmo tempo, também

\footnotetext{
${ }^{1}$ PERROT, Michelle. Os excluídos da história: operários, mulheres, prisioneiros. Rio de Janeiro. Paz e Terra, 1988, p. 67-69. O historiador E. P. Thompson também se preocupou com a questão do tempo e da disciplina do trabalho no período de afirmação do capitalismo industrial inglês. Conferir: THOMPSON, E. P. "Tempo, disciplina de trabalho e capitalismo industrial". In: Idem. Costumes em comum: estudos sobre a cultura popular tradicional. São Paulo: Companhia das Letras, 1998.

${ }^{2}$ A discussão sobre o "sistema fábrica-vila operária" pode ser devidamente encontrada em: LOPES, José Sérgio Leite. "Fábrica e Vila Operária: considerações sobre uma forma de servidão burguesa". In: Idem. [et al.] Mudança Social no Nordeste: a reprodução da subordinação (estudos sobre os trabalhadores urbanos). Rio de Janeiro: Paz e Terra, 1979; CORREIA, Telma de Barros. Pedra: plano e cotidiano operário no sertão. Campinas: Papirus, 1998; TEIXEIRA, Palmira Petratti. A fábrica do sonho: trajetória do industrial Jorge Street. Rio de Janeiro: Paz e Terra, 1990.

${ }^{3}$ Para maior compreensão dessa discussão, consultar a introdução e o primeiro capítulo de: CHALHOUB, Sidney. Trabalho, lar e botequim. O cotidiano dos trabalhadores no Rio de Janeiro da belle époque. São Paulo: Brasiliense, 1986, p. 27-48.
} 
reforçavam certas dimensões de uma cultura de ofício que remonta aos primórdios da organização do trabalho ferroviário ${ }^{4}$.

Considerando esses aspectos, o engenheiro Miguel de Teive e Argollo ${ }^{5}$, diretor principal da Estrada de Ferro do São Francisco, em 1893 desenvolveu um estatuto disciplinar para os trabalhadores da estrada de ferro que estava em plena sintonia com a nova ideologia do trabalho corrente na Primeira República. A elaboração de mecanismos de disciplinarização não era uma ação exclusiva ou isolada dos administradores da ferrovia na Bahia. Aldrin Castellucci, por exemplo, identificou semelhante processo quando da discussão, na Assembleia Legislativa da Bahia, do "Projeto de Código Rural", em 1893, que pretendia forçar, de forma disciplinada, os operários rurais e urbanos ao trabalho. O Projeto só não foi aprovado em razão da vigorosa oposição organizada pelo Centro Operário da Bahia ${ }^{6}$.

O importante regulamento interno elaborado por Teive e Argollo, escrito ainda sob o calor do fim da escravidão, tinha o intuito de ordenar, regular e disciplinar os empregados para o trabalho no prolongamento da Estrada de Ferro do São Francisco. Tratava-se de um manual de normas e instruções de quatrocentos e cinquenta páginas, com mais de mil artigos dispondo sobre regras e orientações acerca da organização do trabalho ferroviário, com proibições, competências, deveres, penalidades, procedimentos, vestimentas, entre outros, que deveriam ser rigidamente seguidos pelos trabalhadores da ferrovia ${ }^{7}$.

O regulamento do prolongamento da estrada de ferro foi divulgado pela diretoria em 26 de junho de 1893, respaldando-se no artigo 111 do regulamento para serviço do tráfego e construção, que fora sancionado pelo decreto $\mathrm{n}-1052$, de 22 de novembro de 1890 . Ao que parece, o autor desse documento, Teive e Argollo, considerava-o completo o suficiente para

\footnotetext{
${ }^{4}$ Uma interessante discussão sobre o trabalho ferroviário pode ser encontrada em: CALVO, Célia Rocha. Trabalho e ferrovia: a experiência de ser ferroviário da Companhia Paulista (1890-1925). 1994. Dissertação (Mestrado em História). PUC, São Paulo, 1994.

${ }^{5}$ Miguel de Teive e Argollo era um empresário e intelectual ocupado com as questões ferroviárias e com os assuntos relacionados ao universo do trabalho. Era também engenheiro civil formado pelo Instituto Politécnico de Rensselaer e membro de diversas sociedades científicas nacionais e internacionais. Oriunda das elites, a família Teive e Argollo esteve ligada aos negócios ferroviários desde os primórdios da implantação da primeira ferrovia na Bahia, em 1858.

${ }^{6}$ CASTELLUCCI, Aldrin. A experiência da escravidão e a constituição de uma identidade operária na Bahia da Primeira República. In: XXIV SIMPÓSIO NACIONAL DE HISTÓRIA, São Leopoldo. Comunicação. São Leopoldo: ANPUH, 15 a 20 jul. 2007.

${ }^{7}$ Regulamento Interno e Instruções Para os Empregados do Prolongamento da Estrada de Ferro da Bahia ao São Francisco. 1893. Bahia. Oficina dos Dois Mundos. 450 p. Fundação Clemente Mariani (doravante FCM).
} 
regular a organização do trabalho e as atividades da ferrovia. Aquele manual deveria entrar em vigor a partir do dia 26 de julho daquele ano, substituindo os demais regimentos: ordem de serviço de 1880 , regulamento de sinais de 1880 , regulamento para foguista e maquinistas de 1881 e regulamento de uniformes de $1883^{8}$.

Não dispomos de informações mais aprofundadas sobre a aplicação, a eficácia ou mesmo o nível de aceitação e as possíveis resistências dos trabalhadores em relação às medidas disciplinares e normas previstas nesse regimento, entretanto isso não nos impede de entender algumas de suas dimensões. Mesmo considerando que se trata de um discurso oficial de instrumento de poder e controle e que, portanto, tenderia a legitimá-lo, Teive e Argollo, no relatório da empresa de 1897, observou os resultados deste regulamento: “[...] o Regulamento Interno que organizei e foi publicado em 1893, produziu os melhores resultados, facilitando aos empregados o conhecimento de suas atribuições, o modo prático de exercê-las" 9 .

Esse regulamento estava estruturado em sete partes, a saber: circular da diretoria, disposições gerais com regras que abrangiam todos os trabalhadores e disposições específicas sobre as funções do tráfego, da locomoção e da linha da estrada, bem como o estabelecimento de normas sobre o uso de uniformes para os empregados. Ademais, trazia na seção de anexos os exemplares do código penal e criminal, entre outros documentos que previam penas em casos de suspensões do trabalho e de greve.

Assim, uma análise mais cuidadosa do Regulamento de 1893 se constitui num valioso recurso para compreender o universo disciplinar da Estrada de Ferro do São Francisco. A abordagem de aspectos pontuais desse documento ajuda, ainda, a elucidar a complexa organização e o processo de trabalho ferroviário no final do século XIX e início do século XX.

\footnotetext{
${ }^{8}$ Regulamento Interno. op. cit., FCM.

${ }^{9}$ Estrada de Ferro do São Francisco. 1897. Relatório apresentado ao Ministro da Indústria, Viação e Obras Públicas pelo Diretor Eng. Miguel de Teive e Argollo, p. 3. Biblioteca Pública do Estado da Bahia (doravante BPEB).
} 


\section{A ORDEM NO TRABALHO}

Em alguns de seus itens mais importantes, o Regulamento, indubitavelmente, apontava para a tentativa de afirmação de uma concepção de trabalho que buscava criar um perfil de trabalhador ordeiro e disciplinado, como se pode ver abaixo em alguns artigos:

Art. 4. Nenhum empregado poderá se ausentar para ponto distante 6 quilômetros daquele em que exercer suas funções sem permissão prévia do Chefe de sua Divisão, ou do Diretor.

Art. 7. Todos os empregados devem obedecer imediatamente às ordens dos seus superiores, isto é, daqueles que pelos regulamentos e instruções em vigor puderem dá-las.

Art. 8. A desobediência a ordens legais, negligência, falta de asseio ou probidade, e a prática de atos imorais, bem como o emprego, em serviço ou nos edifícios da Estrada, de palavras que ofendam ao decoro público, serão punidos severamente.

Art. 13. Os empregados que em serviço nos edifícios e dependências da estrada tiverem altercações entre si ou com pessoas alheias à administração, serão punidos, ainda mesmo que tenham sido provocados.

Art. 14. O local de moradia de cada empregado deve ser lançado em livro especial da Divisão a que pertence, devendo ser comunicadas as mudanças que fizerem.

Art. 16. Todos os empregados, quando em serviço, devem conservar-se decentemente vestidos e asseados.

Art. 18. Os empregados que são obrigados a andar uniformizados não poderão se apresentar em serviço nem desempenhar os deveres a seus cargos sem os respectivos uniformes.

Art. 20. Todos os empregados que por desobediência, ignorância, desídia, incúria ou falta de cumprimento dos regulamentos, ordens e instruções em vigor, derem causa a acidente, além de serem imediatamente exonerados, ficarão responsáveis perante os tribunais do país pelas suas consequências.

Art. 21. Todos os empregados são responsáveis por qualquer prejuízo que causarem à Estrada, resultante de má interpretação, engano, abuso, ignorância ou incúria ${ }^{10}$.

Conforme é indicado nos artigos, o regulamento procurava reforçar a interiorização da disciplina do trabalho ao destacar a hierarquia, a obediência e o respeito aos superiores. Além disso, também era ressaltada a importância da fiscalização mútua, da ordem e da moralidade, prevendo a aplicação de punições aos trabalhadores considerados insubmissos.

Essa mesma perspectiva foi constatada no clássico estudo de Domingos Giroletti sobre o processo de formação da força de trabalho industrial no Brasil, com ênfase nos trabalhadores nacionais. Dentre outras importantes dimensões abordadas, destacam-se as ações empresariais que pretendiam transformar os trabalhadores nacionais em operariado industrial, acionando, para tanto, um conjunto de medidas repressivas e reguladoras que previam a formação disciplinar e a reforma moral daqueles sujeitos. As fábricas funcionaram

${ }^{10}$ Regulamento Interno. op. cit., BPEB. 
como espaço privilegiado para incutir a disciplina do trabalho e produzir esse tipo ideal de operariado, ou seja, dócil e produtivo. Aqui também, assim como na Estrada de Ferro do São Francisco, "o direito criado pelos regulamentos prevendo penalidades e estímulos materiais foi um dos principais meios utilizados para especificar os valores a serem transmitidos ao corpo do operário e para criar nele uma nova cosmovisão"11.

Seguramente, o regulamento de 1893 não pode ser tomado como expressão absoluta das relações cotidianas de trabalho desenvolvidas no prolongamento da Estrada de Ferro do São Francisco, ${ }^{12}$ mas esse documento não pode ser ignorado em nossa reflexão, uma vez que oferece elementos para a compreensão do universo de trabalho ferroviário e sua organização do trabalho.

Ao que parece, o cotidiano de trabalho na ferrovia não era nada aprazível. Contando com a vigilância permanente dentro da empresa, os trabalhadores enfrentavam, diariamente, um conjunto de penalidades e multas aplicadas às suas supostas infrações ${ }^{13}$. Essas punições poderiam corresponder, por exemplo, à redução de vencimentos ou mesmo à suspensão e/ou demissão de operários.

Nessa condição encontraram-se o operário Paulo Pereira Mota e outros empregados da ferrovia em 1897. Esses trabalhadores, em decorrência das normas da estrada, foram obrigados pela empresa a pagar a importância de quarenta e seis mil e novecentos réis (46\$900) aos reclamantes Soares \& Companhia pelo estrago causado em seus produtos, devido, segundo consta, às manobras da locomotiva. Já o ajudante de trem Januário de Souza teve de restituir a quantia de sete mil e trezentos e cinquenta réis $(7 \$ 350)$ pela não entrega da mercadoria em seu lugar de destino ${ }^{14}$.

Tudo indica que essa situação não foi exclusiva de Paulo e Januário. Outros trabalhadores tiveram de responder pelo desaparecimento de mercadorias e descarrilamentos de locomotivas. Isto confirma que a culpa recairia sobre operários

\footnotetext{
${ }^{11}$ GIROLETTI, Domingos. Fábrica: convento e disciplina. Ed. Revista. Brasília: Editora UnB, 2002, p. 33.

${ }^{12}$ Para uma maior explicitação dessa discussão, consultar: PERROT, M. Os operários e as máquinas na França durante a primeira metade do século XIX. In: Idem. op. cit.

${ }^{13} \mathrm{O}$ uso dos regulamentos no espaço de trabalho e, consequentemente, a aplicação de multas como medidas que intensificavam a experiência de exploração vivenciada pelos trabalhadores foram tratados em: MATTOS, Marcelo Badaró. Escravizados e livres: experiências comuns na formação da classe trabalhadora carioca. Rio de Janeiro: Bom Texto, 2008.

${ }^{14}$ Reclamações. In: Estrada de Ferro do São Francisco. Relatório do ano de 1897, apresentado ao Ministro da Indústria, Viação e Obras Públicas pelo Diretor Eng. Miguel de Teive e Argollo. BPEB.
} 
envolvidos em casos desse tipo, tal como estipulava o regulamento. Ao trabalhador era atribuída uma responsabilidade sem precedentes.

As ocorrências de extravios de mercadorias, de baixo desempenho nas atividades, do baixo nível de perfeição do trabalho nas oficinas quando aquém do esperado e dos acidentes de trabalho, eram acompanhadas de severas punições, de exposição à legislação penal e criminal, além de multas - que, inclusive, constavam nas receitas contábeis da empresa. Em casos de acidentes ferroviários, era averiguada a culpa do trabalhador e não a da empresa. Isso fica evidenciado em inquéritos policiais sobre acidentes com vítimas, em que o questionamento principal era acerca do grau de culpabilidade dos maquinistas e não da companhia.

\section{ORGANIZAÇÃO DO TRABALHO NA FERROVIA}

De acordo com o regulamento, a seção de tráfego, embora ligada ao setor de movimentação de trens e locomotivas, possuía mais atribuições burocráticas, administrativas e de operação dos trens. Em linhas gerais, esta seção era responsável pela emissão de bilhetes, recebimento de encomendas e mercadorias, envio e acompanhamento da disposição de sinais para o pessoal da linha e das estações, favorecendo, assim, a circulação e o movimento dos trens. A observância desses sinais era uma atividade de suma importância na execução e operacionalização do transporte ferroviário. Esses sinais codificados tornavam o trabalho na ferrovia bastante complexo, pois exigiam grande atenção dos operadores das locomotivas, do pessoal da linha e das estações, de modo que, uma vez mal interpretados ou incorretamente usados, poderiam provocar descarrilamentos ou acidentes trágicos.

Essa seção contemplava várias funções. Os condutores eram a autoridade máxima dentro do trem. Eles eram responsáveis pela segurança e conduta de todos os empregados, irregularidades, problemas na linha etc. Após as viagens, os condutores poderiam elaborar relatórios mencionando atrasos, o não cumprimento dos regulamentos por parte dos demais empregados, além de injúrias e agressões. Estes trabalhadores deveriam estar disponíveis das seis horas da manhã, horário de partida do primeiro trem, até as dezoito horas. Eles poderiam, ainda, tanto ser responsabilizados por possíveis acidentes, caso não 
cumprissem os regulamentos, quanto responsabilizar os empregados dos trens pelos danos ou perdas de volume etc. Já os ajudantes eram auxiliares dos condutores, podendo substituílos em caso de necessidade, com risco de responder também nas ocorrências de faltas ou negligência dos demais ${ }^{15}$.

Além destes, havia os bagageiros - que eram responsáveis pela conferência e distribuição de mercadorias e bagagens - e os guarda-freios, ambos subordinados aos condutores. Os guarda-freios eram encarregados de manipular os freios, lubrificar as locomotivas, apresentar os sinais, limpar os trens e auxiliar os condutores nas manobras. Não poderiam fumar nas estações e nos trens, conversar com passageiros e outros trabalhadores, nem "usar vestimentas ou objetos encarnados"16, "andar descalços e indecentemente vestidos, ou de tamancos" etc. Consta que um guarda-freios era escolhido para coordenar e fiscalizar o trabalho dos demais, embora desempenhasse as mesmas funções daqueles ${ }^{17}$. Pelo visto, dentre os empregados que trabalhavam dentro do trem, os guarda-freios eram os que possuíam uma posição de menor destaque, tanto que, quando estivessem nas estações, assinavam o mesmo livro de ponto dos serventes.

A seção de tráfego ainda contava com o trabalho dos agentes, fiéis (auxiliares imediatos), telegrafistas, conferentes, guarda-chaves, serventes, guardas e bombeiros. Excetuando os chefes do tráfego, os agentes das estações tinham maior prestígio e poder entre os demais empregados da ferrovia. Os trabalhadores de outras repartições também ficavam sob a tutela destes funcionários (como, por exemplo, os maquinistas), quando estavam em serviço nas estações. Cabia aos agentes inspecionar e fiscalizar, conforme o regulamento, todas as atividades de sua repartição.

Eles eram responsáveis pela fiscalização das irregularidades no espaço do trabalho e pela comunicação destas aos chefes imediatos. Os agentes ainda conferiam a assinatura do ponto de seu pessoal; os retardatários sofreriam descontos em seus vencimentos e poderiam até perder o dia, caso se retirassem antes do fechamento da estação ${ }^{18}$ ou sem a

\footnotetext{
${ }^{15}$ Regulamento. op. cit. Consultar os artigos específicos para condutores de trem, ajudantes, p. 17-30. FCM.

${ }^{16}$ É possível que a proibição quanto ao uso de "vestimentas ou objetos encarnados" esteja associada ao fato de que o serviço ferroviário demandava um conjunto de sinais e códigos muitas vezes baseado na simbologia da cor. O uso de roupas com determinadas cores poderia confundir e comprometer alguns trabalhadores que guiavam as locomotivas, pois estes dependiam desses sinais para seguir ou não o tráfego.

${ }^{17}$ Regulamento. op. cit. Ver as disposições específicas para guarda-freios, p. 93 - 114. FCM.

${ }^{18} \mathrm{~A}$ abertura das estações deveria acontecer uma hora antes da partida do primeiro trem, ou seja, às cinco horas da manhã, e fechar-se antes das dezoito horas.
} 
permissão prévia de superiores. Ademais, inspecionariam o uso dos uniformes dos empregados e comunicariam seus horários de repouso e as horas de trabalho. Os agentes também eram orientados a acompanhar os trabalhos dos funcionários da via permanente ${ }^{19}$, quando estes estivessem nas estações, para evitar que esse pessoal se ausentasse de suas atividades ou se distraísse com conversas ${ }^{20}$. O silêncio e a ordem no trabalho eram aspectos muito importantes para a construção da disciplina almejada pela diretoria. O regulamento reforçava, além de uma perspectiva disciplinadora, relações hierarquizadas entre os trabalhadores.

A seção de locomoção compreendia os chefes de depósito, os maquinistas, os foguistas, o apontador, o encarregado de depósito e trem de lenha e o pessoal das oficinas (especificamente, o mestre-geral, o contramestre e os trabalhadores) ${ }^{21}$. Abaixo dos chefes da locomoção, os chefes de depósito eram a autoridade maior dentro dessa hierarquia. Eles deveriam, entre outras coisas, fiscalizar o trabalho de seus subordinados (especialmente, os foguistas e os maquinistas), verificando as ocorrências de atrasos e ausências. Em tais casos eram aplicados descontos salariais e penalidades ${ }^{22}$.

De acordo com o regimento, os maquinistas trabalhariam cerca de doze horas por dia e deveriam executar suas atividades em voz baixa, evitando gritos. Quando não estivessem em serviço na linha ou nas oficinas, mesmo em períodos de descanso, eram obrigados a permanecer nos depósitos, acompanhando a limpeza e a verificação de suas máquinas, tendo ainda a possibilidade de ser convocados ao trabalho antes das seis horas da manhã ${ }^{23}$.

A direção dos serviços das oficinas ficava a cargo do mestre-geral, responsável por exigir dos operários que as obras fossem executadas tanto com "perfeição" quanto com o menor tempo dispensado. Para se tornar mestre-geral, o trabalhador deveria ser mecânico, detentor de "conhecimentos teóricos e práticos nos serviços a vapor". O mestre-geral

\footnotetext{
${ }^{19}$ A via permanente referia-se ao trabalho realizado pelos operários da seção da linha.

${ }^{20}$ Regulamento. op. cit. Ver os artigos para agentes, conferentes, telegrafistas e ajudantes, p. 63-147. FCM.

${ }^{21} \mathrm{O}$ foguista era uma espécie de auxiliar dos maquinistas. Em serviço dentro das locomotivas, estava submetido às ordens dos maquinistas, devendo atentar para as marchas, a observação dos sinais, lubrificação, alimentação e limpeza das locomotivas. Caso fosse necessário, poderia assumir as atribuições dos maquinistas ou mesmo almejar assento definitivo nesse cargo. Registrava ainda o regulamento, em relação ao serviço dos foguistas, que "deve ser feito com calma e sem motim, trocando apenas com o maquinista em voz baixa as observações necessárias ao serviço, fazendo-lhe... as comunicações do que tiver notado na linha ou no trem, sendo-Ihe proibido dar gritos e conversar". Foguistas. In: Regulamento. op. cit. p. 200-205. FCM.

${ }^{22}$ Regulamento. op. cit., p. 148-337. FCM.

${ }^{23}$ Regulamento. op. cit., p. 160-200. FCM.
} 
deveria conferir a assinatura do ponto do pessoal das oficinas, obrigando-os a cumprir os horários de trabalho, bem como acompanhar o pagamento destes. Além disso, exigia respeito às normas do regulamento e fiscalizava as aptidões, honestidade e zelo de seus subordinados. Convém dizer que isso implicava também a inspeção dos aspectos morais dos empregados.

Eram atribuições de seus auxiliares, os contramestres, determinar o cumprimento das ordens superiores, forçar os empregados a andar bem vestidos e a executar trabalhos. $\mathrm{Na}$ previsão de possíveis conflitos entre trabalhadores, de suspensões de trabalho ou mesmo de greves, o regulamento também orientava o contramestre a comunicar ao mestregeral qualquer suspeita de "projetada medida que pretenda intentar qualquer operário ou grupo de operário em prejuízo do serviço, ou desacato a qualquer empregado da estrada" 24 .

As oficinas principais daquela estrada estavam localizadas nos municípios baianos de Aramari, Queimadas e Vila Nova - a primeira possuía as principais unidades de trabalho. No povoado de Aramari concentravam-se as oficinas de ferraria - onde ficavam os ajustadores, torneiros, caldeireiros e ferreiros - e de carpintaria ${ }^{25}$.

Cabe observar que a tentativa de enquadrar os operários nas oficinas, fixando-os ao local de trabalho e controlando seus níveis de produção e socialização, constituía-se numa determinação nítida, como se observa nos artigos que se seguem:

Art. 684 Nenhum operário poderá ausentar-se da sua bancada ou da máquina em
que estiver trabalhando, sem a prévia licença ou ordem de seu contra, ao qual deve
igualmente pedir permissão para retirar-se, quando por moléstia ou outro motivo
tiver de fazê-lo.
Art. 688 A cada operário será distribuída uma placa com o número que lhe
corresponde no livro de ponto. Nessa placa o operário escreverá o serviço feito
durante as horas em que esteve trabalhando em cada dia, mencionando a hora que
começou cada trabalho, ou peça...
Art. 694 Cada operário, ao entrar para as oficinas e antes de se dirigir para seu
respectivo lugar, tirará em presença do apontador a chapa que tem o número que
lhe corresponde e a deitará dentro da gaveta da banca do mesmo apontador por
uma fresta, feita exclusivamente para esse fim no lastro da dita banca.
Art. 695 O operário que, depois de tirar a sua chapa, ausentar-se sem a devida
comunicação expressa no Art. 685 , será punido de conformidade com o Art. 80 do
Regulamento em vigor, dando-se o mesmo para com o operário que tirar a chapa
de qualquer dos seus companheiros.
Art. 701 É expressamente proibido conversar dentro das oficinas. As ordens aos
operários e contramestres serão dadas em voz baixa... Os operários que

${ }^{24}$ Regulamento. op. cit., p. 323-324. FCM.

${ }^{25}$ Relatório da Estrada de Ferro do São Francisco. 1897, apresentado ao. Exmo. Ministro da Indústria, Viação e Obras Públicas pelo Eng. Miguel de Teive e Argollo, p. 45. BPEB. 
levantarem a voz, retrucarem em altas vozes ou altercarem serão obrigados a retirar-se imediatamente das oficinas ${ }^{26}$.

No interior das oficinas, o apontador exercia uma função muito importante na lógica disciplinar da empresa, de modo que, além de organizar o ponto dos operários, era responsável direto pela vigilância da movimentação e presença dos trabalhadores dentro do espaço de trabalho. Conforme determinação do regimento, o apontador deveria, diariamente, examinar a assinatura do ponto. Uma tabela e as respectivas chapas de cobre, ambos com os correspondentes números dos operários, seriam dispostas sobre a mesa.

Nesse ritual, cada operário, na "presença" do apontador, recolheria uma chapa, correspondendo ao seu número de cadastro, e a introduziria "na gaveta da referida mesa por uma fenda a esse fim destinado, dirigindo-se incontinente para o seu trabalho" ${ }^{27}$. A assinatura do "ponto" do pessoal era uma cena importante, pois representava a afirmação simbólica das relações hierárquicas no universo de trabalho das oficinas ${ }^{28}$. É pertinente lembrar que a atenta supervisão dos apontadores e mestres de linha, com a missão de garantir o silêncio e o movimento "incontinente" para o trabalho, constituía-se num incremento a mais à imagem de poder inconteste e de uma ordem necessária.

\footnotetext{
${ }^{26}$ Oficinas. In: Regulamento. op. cit. Consultar artigos 680 a 706. FCM.

${ }^{27}$ Apontador. In: Regulamento. op. cit., p. 869 - 877. FCM

${ }^{28}$ A obra A tecelagem dos conflitos, de José Leite Lopes, é uma referência importante para a compreensão de rituais de dominação no mundo do trabalho, que ele denominou de "teatralização da dominação". Seu estudo conseguiu demonstrar como os patrões procuravam interiorizar a disciplina e a dominação nos empregados da fábrica têxtil Paulista, no estado de Pernambuco. Esses rituais envolviam códigos tradicionais de dominação. LOPES, José Sergio L. A tecelagem dos conflitos de classe na "cidade das chaminés". São Paulo: MCT/CNPq, Marco Zero, 1988.
} 
Figura 1: Vista do interior da oficina

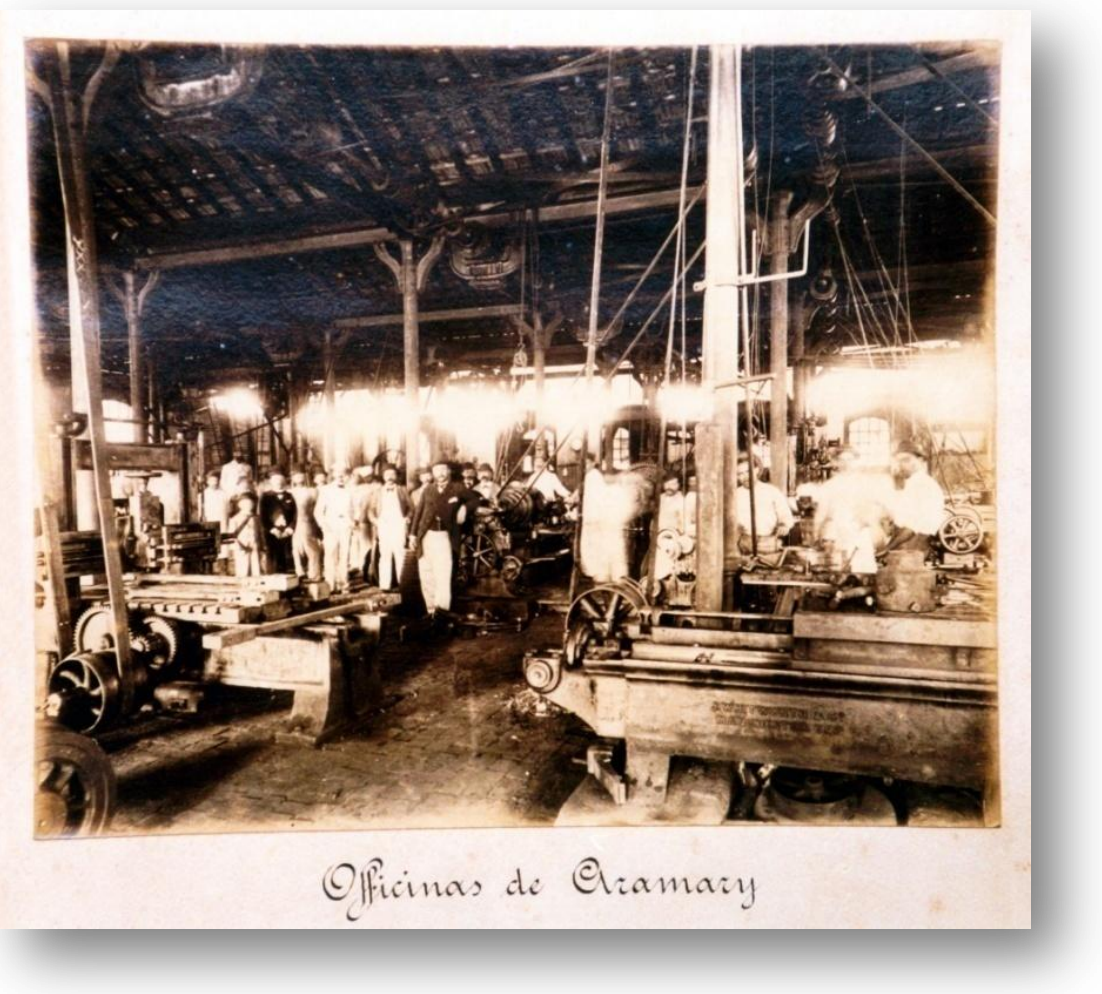

Fonte: Planta da Estrada de Ferro do São Francisco. 1900. RFFSA.

Finalmente, a estrada de ferro contava ainda com os serviços dos trabalhadores da seção da linha. A repartição de linha era constituída por condutores, mestre de linha, armazenistas, encarregados de obras, guarda-raios, guardas, feitores e turmas de trabalhadores. Estes últimos correspondiam, quantitativamente, à maior parcela da mão de obra da estrada de ferro.

Esses trabalhadores estavam distribuídos entre "titulados" ou "mensaleiros" aqueles que ocupavam empregos fixos - e os "jornaleiros" - recrutados para trabalhar como diaristas. Em se tratando da divisão do trabalho, sabe-se que havia o pessoal que, ganhando maiores vencimentos, era responsável pelas atividades desenvolvidas em seus respectivos setores. Tudo indica que os salários dos operários variavam de acordo com as profissões ocupadas, de modo que quanto mais especializado fosse o serviço maior seria a remuneração alcançada. Há evidências de que os trabalhadores ordinários recebiam valores mensais superiores aos demais, e os diaristas ${ }^{29}$, que compunham a maioria dos operários, geralmente recebiam os mais baixos rendimentos, como mostra a tabela 1 :

\footnotetext{
${ }^{29}$ Regulamento. op. cit. Estabelecia que "só pode ser apontado meio dia [de trabalho] aos operários que trabalharem mais de cincos horas no mesmo dia. O tempo do pessoal jornaleiro é contado na linha no serviço, 
Tabela 1 - Rendimentos dos Trabalhadores da E. de Ferro do São Francisco, 1898

\begin{tabular}{|c|c|c|}
\hline \multicolumn{3}{|c|}{ Pessoal titulado } \\
\hline \multicolumn{3}{|c|}{ Vencimento mensal (em réis) } \\
\hline 1 chefe de linha & & $700 \$ 000$ \\
\hline 1 escriturário & & $160 \$ 000$ \\
\hline 1 armazenista & & $150 \$ 000$ \\
\hline 10 mestres de linha & & $1: 500 \$ 000$ \\
\hline \multicolumn{3}{|c|}{ Pessoal diarista } \\
\hline & Diária máxima & e mínima \\
\hline 1 reparador de instrumentos & & $6 \$ 000$ \\
\hline 1 recebedor de dormentes & & $7 \$ 000$ \\
\hline 4 carapinas & $5 \$ 800$ & $3 \$ 000$ \\
\hline 1 ferreiro & & $4 \$ 200$ \\
\hline 1 malhador & & $2 \$ 200$ \\
\hline 7 pedreiros & $4 \$ 000$ & $2 \$ 000$ \\
\hline 50 feitores & $3 \$ 200$ & $2 \$ 000$ \\
\hline 265 operários & $1 \$ 500$ & $1 \$ 400$ \\
\hline 1 ajudante de carapina & & $2 \$ 500$ \\
\hline 1 zelador de açude & & $2 \$ 000$ \\
\hline 2 serventes & $1 \$ 600$ & $1 \$ 500$ \\
\hline 7 vigias & $1 \$ 500$ & $1 \$ 400$ \\
\hline 16 bombeiros & $1 \$ 500$ & $1 \$ 400$ \\
\hline 1 maquinista & & $3 \$ 000$ \\
\hline 1 ajudante & & $1 \$ 500$ \\
\hline Total: 372 & & \\
\hline
\end{tabular}

Fonte: Estrada de Ferro do São Francisco. Ministério da Agricultura. 1899. http://www.crl.edu/content.asp

Não foi preciso grande esforço para constatar que as menores diárias eram concedidas aos operários (turmas de trabalhadores), aos vigias e aos bombeiros. É bem provável que esse fato esteja relacionado ao grau de qualificação desses trabalhadores. No caso dos "operários", como registrado no quadro acima, cujos valores variavam entre $1 \$ 400$ a $1 \$ 500$ (réis), é possível que a empresa levasse em consideração o fato de se tratar de trabalhadores braçais, responsáveis pela manutenção da estrada de ferro. Em outras palavras, certamente esses parcos vencimentos eram creditados ao desprestígio que serviços manuais tinham naquela sociedade, além do que, por ser considerado um ofício "desqualificado", a empresa contava com mão de obra abundante no mercado de trabalho. Esta situação diminuía a dependência da companhia em relação ao mercado de trabalho e criava, assim, condições ideais para que se pudesse estabelecer a política salarial que melhor Ihe conviesse. Estes trabalhadores menos qualificados, que vimos recebendo as menores 
remunerações na tabela 1 tinham cor e identidades bem marcadas. Eles iam além do mero dado estatístico. Na figura 2 podemos perceber um pouco quem eles eram.

\section{Figura 2 - Trabalhadores da linha no início do século XX}

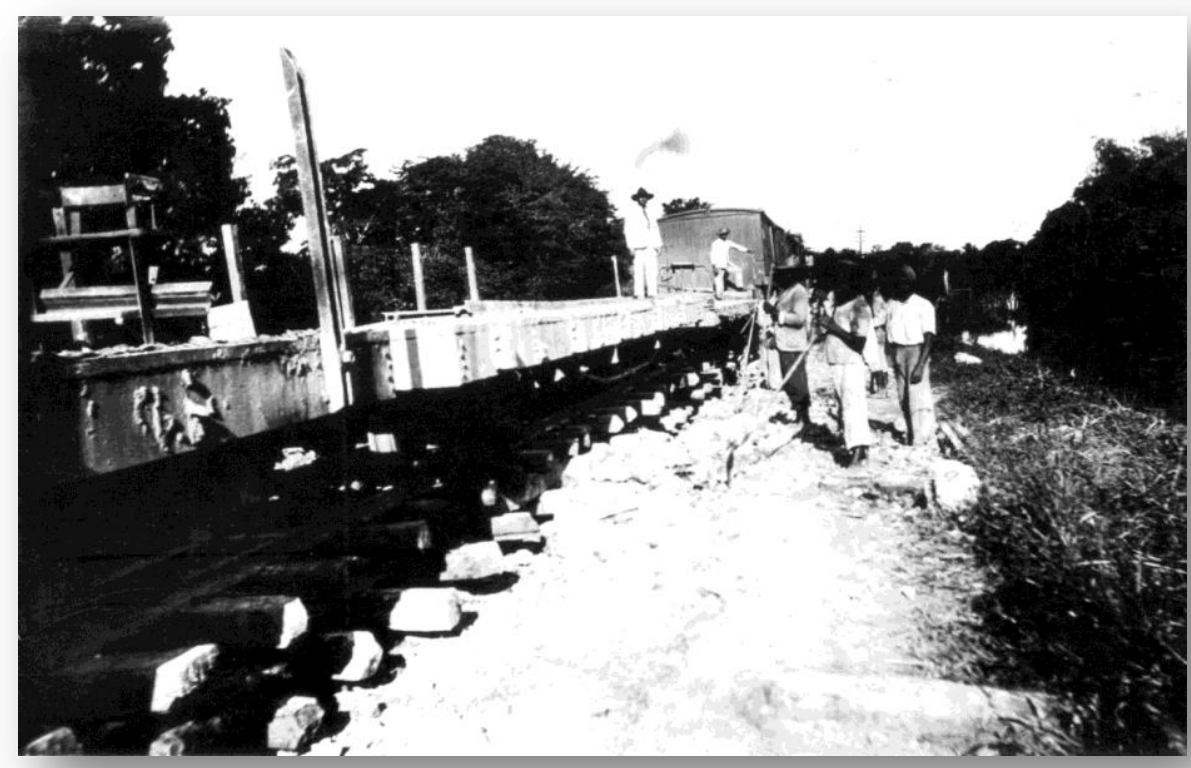

Fonte: Planta da Estrada de Ferro do São Francisco. 1900. RFFSA.

Eis na fotografia acima uma imagem dos trabalhadores da linha no início de 1900. Note-se que no alto do trem estão dois empregados da estrada. Talvez fossem mestres de linha ou outros empregados "mensalistas" ou mesmo um dos feitores de turmas. No plano mais baixo encontravam-se os trabalhadores das turmas, todos negros, a empregar sua força de trabalho nos serviços braçais de conservação e manutenção das linhas férreas. Considerando-se que na Bahia, diferentemente de São Paulo e Rio de Janeiro, o fluxo de imigrantes durante a Primeira República foi quase insignificante, verificamos nessa fotografia evidências importantes da presença de afrodescendentes na estrada de ferro ${ }^{30}$. Em nossa ótica, a experiência negra surge aqui como fator diacrítico no processo de

\footnotetext{
${ }^{30}$ Consultando outras fotografias da RFFSA, constatamos que negros e mestiços têm uma presença marcante no espaço de trabalho ferroviário. Verificar os registros visuais da: Planta da Estrada de Ferro do São Francisco. 1900. op. cit; Sobre a questão da preponderância do perfil étnico-racial negro na classe trabalhadora baiana, consultar: CASTELLUCCI, Aldrin A. S. Industriais e operários baianos numa conjuntura de crise (1914-1921). Salvador: Fieb, 2004, p. 75.
} 
formação da classe trabalhadora urbana baiana, especificamente no universo ferroviário, no período do pós-abolição ${ }^{31}$.

Para melhor entender a organização do trabalho na seção da linha e a sua lógica disciplinar, serão analisadas as relações de trabalho entre os feitores e as "turmas de trabalhadores", uma vez que esses dois grupos, além de serem majoritários, tinham funções interdependentes, com suas trajetórias e seus conflitos diretamente imbricados, sendo o segundo a condição e a razão de existência do primeiro.

O oficio de feitor não foi uma atividade exclusiva do universo de trabalho das estradas de ferro na Bahia. A figura do feitor era comum em outras ferrovias e em outros postos de trabalho no país, remetendo-nos, inclusive, ao período da escravidão. Esse personagem exercia um papel importantíssimo no sistema de manutenção e controle do trabalho escravo. Investido de poder e autoridade, ele representava a linha intermediária entre os senhores e os escravos. A sua função era a de organizar o trabalho, fazendo com que os escravos produzissem com regularidade e com ritmo nas fazendas, além de castigar os trabalhadores escravos considerados indolentes e insubmissos. Enquanto peça importante na manutenção da ordem escravista, segundo Silvia Lara, "o feitor, "braço de que se vale o senhor para o bom governo da gente e da fazenda', era ao mesmo tempo figura da violência e ordenador do trabalho no interior da unidade de produção"32.

Na relação hierárquica da empresa ferroviária, os feitores só exerciam poder de mando sobre as turmas de trabalhadores. Presentes apenas na repartição de linha e conservação das estradas, os feitores tinham a função específica de cuidar da ordem, garantir o ritmo do trabalho e controle das atividades, além de manter sob vigilância e

\footnotetext{
${ }^{31}$ Dentre outros estudos sobre a participação dos trabalhadores negros na trajetória da classe operária brasileira durante a Primeira República, consultar: VELASCO e CRUZ, Maria Cecília. Virando o jogo: estivadores e carregadores no Rio de Janeiro da Primeira República. 1998. Tese (Doutorado em Sociologia)- FFLCH-USP, 1998; Idem. Tradições negras na formação de um sindicato: Sociedade de Resistência dos Trabalhadores em Trapiche e Café, Rio de Janeiro, 1905-1930. Afro-Ásia, Salvador: Ceao-UFBA, n. 24, p. 243-290, 2000; ARANTES, Érika Bastos. O Porto Negro: cultura e trabalho no Rio de Janeiro dos primeiros anos do séc. XX. 2005. Dissertação (Mestrado em História) - Instituto de Filosofia e Ciências Humanas, UNICAMP, Campinas, 2005; LONER, Ana Beatriz. Construção de classe: operários de Pelotas e Rio Grande (1888-1930). Pelotas: Editora da UFPEL/Unitrabalho, 2001.

32 LARA, Silvia H. Campos da violência: escravos e senhores na Capitania do Rio de Janeiro, 1750-1808. São Paulo: Paz e Terra, 1988, p. 54. A autora faz interessante discussão sobre o papel do feitor no regime escravista, tendo como interlocutor a obra Cultura e Opulência no Brasil, de André João Antonil. Conforme a enciclopédia portuguesa e brasileira, volume $\mathrm{XI}$, o termo poderia significar: "capataz; aquele que dirige e manda os trabalhadores". Dessa forma, não é nossa intenção estabelecer uma relação direta entre o oficio de feitor e a escravidão; apenas objetivamos mostrar a historicidade desse ofício nas relações de trabalho no Brasil.
} 
fiscalização todos os trabalhadores, fazendo cumprir as determinações dos mestres de linha e as demandas do serviço ferroviário. Vejamos as determinações que se seguem:

\begin{abstract}
Art. 1.077 Em todos os serviços o feitor deve trabalhar com os trabalhadores; Art. 1.078 Para os feitores e trabalhadores o serviço começará e terminará às horas designadas pelo Diretor, havendo uma hora de descanso.

Art. 1.082 Os feitores das turmas tem o dever:

\$8 Conservar a boa ordem e moralidade no seu pessoal, dando parte quando houver insubordinados para serem punidos.

Art. 1.093 Os feitores serão responsáveis pelos atos dos trabalhadores de suas turmas, desde que não empreguem todos os meios para coagi-los a proceder bem, e não comuniquem as faltas em que tiverem incorrido, ou souberem, que não pretendem cometer aos mestres de linhas.

Art. 1.096 Os feitores serão obrigados a instruir o pessoal sob suas ordens dos deveres que lhes são impostos pelos regulamentos, instruções e ordens em vigor.

Art. 1.099 Os feitores terão sempre em lembrança que devem fazer os mesmos trabalhos que não lhe competirem,..., e trabalhar e fazer trabalhar proveitosamente para a Estrada o pessoal sob suas ordens ${ }^{33}$. (grifos do autor)
\end{abstract}

A deflagração de conflitos diretos entre feitores e operários era quase inevitável, e os considerados turbulentos imediatamente punidos. No dia 29 de janeiro de 1891, por exemplo, os trabalhadores Pedro Rocha, Procópio Nunes, José Victor e Luiz Bispo, após serem multados, abandonaram o trabalho na estrada de ferro. Segundo os relatórios da empresa, os quatro trabalhadores foram multados por terem se insubordinado contra o seu feitor, "maltratando-o com palavras injuriosas". Convém assinalar que os trabalhadores que protagonizaram esse conflito foram alvo de represálias por parte da empresa ${ }^{34}$.

Era dentro desses limites que se operavam as ações dos feitores da estrada de ferro. No entanto, é bom lembrar que, mesmo exercendo sua prerrogativa de poder e autoridade sobre os trabalhadores turmeiros, os feitores poderiam ser responsabilizados pelos patrões caso descumprissem suas ordens ou falhassem na execução de suas atribuições. Isso indica que, embora fosse investido de certo domínio sobre os trabalhadores de sua turma, o poder exercido pelo feitor era restrito; era um poder circunscrito a um universo específico e sobre sujeitos determinados.

Dessa maneira se projetou a história de Manoel de Almeida nos idos de 1891. Em 13 de agosto daquele ano, Manoel, feitor de turma, passou a ser protagonista de um acidente que resultou na sua demissão. Ao que parece, o trole (espécie de bonde) conduzido pela

\footnotetext{
${ }^{33}$ Feitores. In: Regulamento... 1893. op. cit., p. 388-398. FCM.

${ }^{34}$ Ocorrências. In: Relatório do ano de 1891 do Prolongamento da Estrada de Ferro da Bahia, apresentado ao Exmo. Sr. Ministro da Agricultura, Comércio e Obras Públicas por Miguel de Teive e Argollo, diretor engenheiro. Instituto Geográfico e Histórico da Bahia (doravante IGHB).
} 
turma desse feitor colidiu com uma locomotiva, deixando ambas as máquinas quebradas. Por isso ele recebeu a seguinte sentença: "sendo o encontro devido à falta de cuidado do feitor, foi este dispensado do lugar" ${ }^{35}$.

\section{LEMBRAR PARA NÃO ESQUECER}

A ideia de que a questão operária era um problema de polícia durante os anos iniciais da Primeira República, muito provavelmente constituiu um dos eixos norteadores do pensamento de Miguel de Teive e Argollo.

Seguindo essas indicações, é possível compreender aspectos do pensamento desse personagem que cuidou de anexar, no já citado Regulamento de 1893, o Código Penal e o Código Criminal de 1890, entre outros. Os Códigos eram documentos oficiais que prescreviam os crimes relacionados aos danos, acidentes, motins, reunião de trabalhadores e suspensões de trabalho (greve), numa nítida demonstração dos episódios que intentavam coibir e dos conflitos que queriam neutralizar. Para efeito de seus objetivos, a estrada de ferro usava da estratégia de lembrar aquelas leis para manter os operários dentro do que era juridicamente permitido.

Nessa perspectiva, atentemos apenas para o decreto que se relacionava diretamente com o mundo do trabalho e os episódios de ações diretas, como, por exemplo, as greves. Trata-se do decreto de 12 de dezembro de 1890, que alterava os artigos 205 e 206 do Código Criminal. Vejamos:

O governo provisório da República dos Estados Unidos do Brasil, [...], e para estabelecer a clareza indispensável sobretudo às leis penais, decreta:

Art. 1. Os artigos 205 e 206 do Código penal e seus parágrafos ficam assim redigidos.

Desviar operários ou trabalhadores dos estabelecimentos, em que forem empregados, por meio de ameaças, constrangimento ou manobras fraudulentas:

Penas - de prisão celular por um a três meses e de multa $200 \$ 000$ a $500 \$ 000$.

Causar ou provocar cessação ou suspensão de trabalho por meio de ameaças ou violência, para impor aos operários ou patrões aumento ou diminuição de salário, ou serviço:

Penas - de prisão celular por dois a seis meses e de multa de $200 \$ 000$ a $500 \$ 000$.

Art. 2. Revogam-se as disposições em contrário.

${ }^{35}$ Ocorrências. In: Relatório do ano de 1891 do Prolongamento. op. cit., IGHB. 
A elaboração de leis e o amparo repressivo contido nelas deveriam assegurar o funcionamento das suas empresas, preservando a propriedade privada e resguardando a "liberdade do trabalho" em momentos de conflito, como, por exemplo, de greves. Aos operários restava o desamparo legal e a criminalização de suas ações pela polícia. Convém ressaltar que, mesmo diante dessa ostensiva proteção legal com que o patronato contava, os trabalhadores enfrentaram a experiência de exploração do trabalho de diferentes formas, ora em embates sutis, ora em confrontos abertos, muitas vezes traduzidos em mobilizações grevistas. Assim, não é demais lembrar as diversas mobilizações operárias que se manifestaram no cenário baiano, nos primeiros anos do regime republicano ${ }^{36}$.

\section{TRABALHAR E MORRER SOBRE OS TRILHOS}

De maneira geral, verificamos a existência de acidentes de trabalho envolvendo operários da estrada de ferro. Em muitos casos, esses desastres resultaram em mortes, tanto entre populares como entre os próprios trabalhadores, como veremos nos exemplos que se seguem.

Na noite de 21 de maio de 1897, na Estação de Jurema, cidade de Juazeiro, o operário Manoel Bispo da Silva, em obediência às ordens do seu feitor, fazia uma ronda na linha férrea da estrada. O feitor Manoel Ignácio da Silva, inquieto pela demora do dito operário, partiu para saber quais as razões e, a certa altura, avistou um vulto entre os trilhos. Era noite e, certamente assustado, o feitor foi buscar o mestre de linha e outros trabalhadores, que confirmaram que o vulto era o de um cadáver esmagado ao longo dos trilhos. Tratava-se do "infeliz operário" Manoel da Silva ${ }^{37}$.

Interrogados pelo comissário de polícia sobre as razões da morte do operário, bem como sobre o grau de culpa do maquinista que dirigia a locomotiva, foi comum entre os trabalhadores depoentes afirmar que não haviam presenciado o acidente. Mesmo estabelecendo os limites de seu depoimento, o operário José Bispo da Silva, 22 anos, natural

\footnotetext{
${ }^{36}$ Cf. FONTES, José Raimundo. Mobilizações operárias na Bahia: o movimento grevista, 1888-1930. 1988. 273 f. Dissertação (Mestrado em Ciências Sociais) - Faculdade de Filosofia e Ciências Humanas - UFBA, Salvador, 1988.

${ }^{37}$ Tribunal de Relação. Seção Judiciária. Série atropelo com morte. Vítima: Manoel Bispo da Silva. Local: Juazeiro. 1897. 38/1337/06. Arquivo Público do Estado da Bahia (doravante APEB). A expressão "infeliz operário" foi extraída dos autos do processo.
} 
do Bonfim, foi além, ao considerar que Manoel Bispo poderia estar "dormindo ou com vertigem $^{\prime 38}$.

Infelizmente não se dispõe de outras informações sobre a "morte do infeliz operário" Manoel. Tampouco é possível afirmar que o acidente foi resultado das extenuantes horas de trabalho na empresa ou mesmo de um descuido da vítima ou do maquinista da locomotiva. No entanto, sabe-se apenas que as turmas de trabalhadores que serviam na linha, na manutenção e na conservação da via permanente, sob as ordens e supervisão dos feitores, exerciam, geralmente, atividades braçais com intensa exposição ao sol e chuvas, o que provocava grande desgaste físico.

Em outro caso, por volta de 1897, mediante a acusação de negligência feita pelo promotor público, o maquinista Adelino Paulino foi levado à Justiça a fim de que fosse apurada a sua responsabilidade pela morte de Aprígio Antonio de Araújo. Ao que parece, Aprígio descansava sua cabeça nos trilhos, na estação de Piranga, em Juazeiro, quando a locomotiva conduzida por Adelino o atingiu fatalmente. Conforme os autos do processo:

\footnotetext{
O Promotor Público da Comarca vem denunciar a V. S. Adelino Paulino, pelo fato que passa a expor.

Achando-se, no dia 21 de maio de 1897, sentado em um dos pontilhos da Estação Piranga, Aprígio Araújo, com a cabeça descansada sobre as mãos, aconteceu que passando por ai uma locomotiva da Estrada de Ferro, que puxava carros de lastro, que tinha partido da Estação do Juazeiro, o braço do fuso do tomo que fica assentado no passeio atingisse o mesmo Aprígio Araújo e o atirasse do pontilhão abaixo, resultando a sua morte.

Tendo a dita locomotiva da estação do Juazeiro, e avistando-se daí o pontilhão onde estava Aprígio, podia o maquinista Adelino Paulino parar a máquina a tempo de não se dar o desastre, o que não o fez por negligência. Ora, como o denunciado com tal procedimento torna-se criminoso, para que então seja punido com médio das penas o art. 297 do Código Penal, o mesmo Promotor vem dar a presente denúncia... ${ }^{39}$ (grifos do autor)
}

O artigo 297 do Código Penal se referia à culpa de homicídio involuntário ${ }^{40}$, e foi a partir dele que o promotor público Antônio Pinto da Silva perseguiu por mais de um ano o maquinista Adelino Paulino. Assim, utilizando-se dos mecanismos legais do sistema judiciário da época, o promotor valeu-se de suas prerrogativas para abrir, arquivar e reabrir o processo de averiguação de culpa do referido maquinista. Em 7 de junho de 1897, o promotor público

\footnotetext{
${ }^{38}$ A expressão "dormindo ou com vertigem" também foi retirada dos autos do processo.

${ }^{39}$ Tribunal de Justiça. Seção Judiciária. Série Denúncia. Réu: Adelino Paulino, maquinista da estrada de ferro. Localidade: Juazeiro. 1898. 18/638/12. APEB.

${ }^{40}$ Encontrei vaga referência ao artigo 297 do Código Penal em: PEREIRA, Marco Aurélio Monteiro. Discurso burocrático e normatização urbana e populacional em Curitiba. Revista de História Regional. v. 5, n. 1. Disponível em: http:www.uepg.Br/rhr/vrn1/marco.htm
} 
solicitou ao juiz que o referido processo fosse reaberto: "Tendo chegado ao meu conhecimento algumas particularidades sobre o acidente [...] e que podem concorrer para o descobrimento da existência ou não [do] crime, peço-vos que dignes mandar que sejam dados com vista os respectivos autos ${ }^{\prime 11}$. Isso significava dizer que, pelo menos até 1898 , Adelino esteve na "mira" da investigação criminal.

Os depoimentos de todos os trabalhadores, segundo os autos do processo, indicaram que o maquinista usou de todos os recursos de que dispunha para evitar que a locomotiva ceifasse a vida do "infeliz" indivíduo. Eles declararam que o maquinista colocara em risco a sua própria vida, ao acionar, através dos sinais e apitos, o guarda-freios para que parasse bruscamente o trem. Alguns deles até demonstraram conhecer o regulamento da estrada, ao confirmar, durante o interrogatório, que era proibida a permanência de pessoas estranhas nos trilhos ${ }^{42}$.

Sem dúvida, esses não eram casos incomuns no trabalho ferroviário ${ }^{43}$. Ao que tudo indica, a estrada de ferro foi cenário de acidentes que implicaram desde a simples destruição ou desgaste de máquinas até a morte de trabalhadores e/ou transeuntes. A seguir, vejamos alguns destes acidentes:

No dia 23 [março], no trem especial, locomotiva n. 37, maquinista Hermenegildo Augusto dos Santos, ponte do Itapicuru-mirim, foi alcançado o reparador Augusto da Silva, que servia de guarda-freio.

No dia 27 [maio], a locomotiva n. 25, maquinista Antonio Moreira da Silva, [...], alcançou um trolley, mais ou menos, estragando o mesmo trolley, ficando a locomotiva bastante avariada.

No dia 26 [novembro], o trem M1, locomotiva n. 37, maquinista Manoel Ferreira de Oliveira, ao passar a ponte de Queimadas, caiu um guarda-freio entre os carros, morrendo instantaneamente ${ }^{44}$.

Outrossim, há evidências de que certos trabalhadores se envolveram em acidentes com regular frequência, o que demonstra que era possível, mesmo após esses episódios, que alguns deles ainda assegurassem seus empregos. Muito provavelmente foi essa a situação vivida pelos maquinistas Antonio Moreira Silva e Alexandre Teles Barreto. Ambos estiveram envolvidos em reincidentes casos de desastres ferroviários por volta do ano de

\footnotetext{
${ }^{41}$ Tribunal de Justiça. Seção Judiciária. Série Denúncia. op.cit., APEB.

${ }^{42}$ Tribunal de Justiça. Seção Judiciária. Série Denúncia. op.cit., APEB.

${ }^{43}$ Pode-se exemplificar com alguns casos publicados no Jornal de Notícias: "Desastre", 20/7/1893; "Acidente na estrada de ferro", 12/1/1894; "Descarrilamentos-mortes-ferimentos", 28/2/1894. BPEB.

${ }^{44}$ Acidentes. In: Relatório. 1897. op. cit., BPEB.
} 
1897. Em um desses acidentes, além da morte do maquinista Teles Barreto, faleceu o foguista Tertuliano Pinto de Carvalho ${ }^{45}$.

Não seria absurdo pensar que a qualificação técnica requerida ao exercício dessa função acabasse interferindo favoravelmente na permanência desses trabalhadores no emprego de maquinista. Isso porque, diferentemente de outros cargos, não deveria ser uma tarefa fácil recrutar operários com o ofício especializado de maquinista no mercado de trabalho da Bahia. Talvez aí resida uma possível explicação.

Ser maquinista da estrada de ferro significava ter certo grau de prestígio em relação a outras profissões. Essa situação deve-se ao fato de o trabalho de condução de trens exigir um nível elevado de conhecimento técnico, e um dos critérios para ocupar tal função, entre outros, era o empregado saber ler e escrever. Esta condição estava distante da realidade da maioria da população baiana no final do século XIX. Apesar disso, a especialização não significava que o trabalho de operação dos trens era um serviço menos desgastante ou que o poder disciplinar incidisse sobre eles de forma mais branda em relação aos outros trabalhadores.

Além dessas ocorrências, encontramos outros desastres que resultaram em danos não somente às máquinas e à pretendida eficiência dos serviços da empresa, mas também, em muitos casos de maneira irreversível, aos seus trabalhadores. Foguistas, guarda-freios, maquinistas e limpadores foram algumas vítimas dos desastres.

Nesses casos, a responsabilidade pelas ocorrências de acidentes, pelo visto, não seria atribuída à empresa. Quando a culpa não recaía sobre o empregado, era transferida ao cidadão, fosse pela Justiça, fosse pela empresa, como sugere a tabela 2:

${ }^{45}$ Acidentes. In: Relatório. 1897. op. cit., BPEB. 
Tabela 2 - Relação de Acidentes ocorridos na estrada de ferro - 1898

\begin{tabular}{|l|c|}
\hline Causas. Colisões & 1 \\
\hline Colisões. Causa - Descarrilamentos por animais na linha & 6 \\
\hline Colisões. Causa - Por outros motivos & 10 \\
\hline Colisões. Causa - Material rodante deteriorado. Locomotivas & 8 \\
\hline Colisões. Causa - Veículos & - \\
\hline Pessoas mortas, viajantes. Por culpa da Estrada & - \\
\hline Pessoas mortas, viajantes. Por culpa própria & - \\
\hline Pessoas mortas, viajantes. Por culpa de terceiros & 2 \\
\hline Pessoas mortas, viajantes. Empregados na Estrada por culpa da Estrada & 2 \\
\hline Pessoas mortas, viajantes. Empregados na Estrada por culpa própria & - \\
\hline Pessoas mortas, viajantes. Empregados na Estrada por culpa de terceiros & 2 \\
\hline $\begin{array}{l}\text { Pessoas mortas, viajantes. Pessoas estranhas à Estrada por culpa a } \\
\text { Estrada }\end{array}$ & - \\
\hline Pessoas mortas, viajantes. Pessoas estranhas à Estrada por culpa própria & - \\
\hline $\begin{array}{l}\text { Pessoas mortas, viajantes. Pessoas estranhas à Estrada por culpa de } \\
\text { terceiros }\end{array}$ & - \\
\hline Pessoas feridas, viajantes. Por culpa da Estrada & - \\
\hline Pessoas feridas, viajantes. Por culpa própria & - \\
\hline Pessoas feridas, viajantes. Por culpa de terceiros & - \\
\hline Pessoas feridas, viajantes. Empregados na Estrada por culpa da Estrada & 6 \\
\hline Pessoas feridas, viajantes. Empregados na Estrada por culpa própria & 1 \\
\hline Total das pessoas mortas & \\
\hline Total das pessoas feridas & \\
\hline
\end{tabular}

Fonte: Relatório da Estrada de Ferro. 1898. BPEB.

A transferência da responsabilidade pelos acidentes aos operários parece não ter sido uma situação exclusiva dos trabalhadores da ferrovia. Outros setores da classe trabalhadora, diante do cenário de acidentes, certamente testemunharam patrões eximindo-se das suas responsabilidades e atribuindo-as aos seus operários. Desse modo, não é por acaso que os trabalhadores reunidos no Primeiro Congresso Operário de 1906 responsabilizaram os patrões pelos acidentes e, em casos extremos, propuseram ações diretas, a exemplo de greves ${ }^{46}$.

Conforme demonstramos, os trabalhadores da Estrada de Ferro do São Francisco, além de expostos às condições precárias de trabalho e de alta insalubridade, estavam submetidos a relações de trabalho altamente hierarquizadas, ordenadas e regidas por um código regulamentar com prescrições repressivas que, extensivamente, os inculpava pelos casos de acidentes.

Essa realidade não foi exclusiva do serviço ferroviário ou resultado de uma ação isolada no Brasil. Com suas peculiaridades, essa realidade está inserida em um contexto

\footnotetext{
${ }^{46}$ MATTOS, Marcelo Badaró. op. cit.; sobre O Primeiro Congresso de 1906, consultar: PINHEIRO, Paulo Sérgio; HALL, Michael M. A classe operária no Brasil (1889-1930). Documentos. Vol. 1 - O movimento operário. São Paulo: Alfa Omega, 1979, p. 54.
} 
histórico mais amplo do desenvolvimento de dispositivos disciplinares que buscavam submeter os trabalhadores ao poder patronal.

Recebido em 08/10/2009

Aprovado para publicação em 12/05/2010 